\title{
Sedimentological and biostratigraphical analyses of short sediment cores from Hagelseewli (2339 m a.s.l.) in the Swiss Alps
}

\author{
André F. LOTTER ${ }^{1,2) *}$, Wolfgang HOFMANN ${ }^{3)}$, Christian KAMENIK $^{4)}$, Andrea LAMI ${ }^{5)}$, Christian OHLENDORF $^{2)}$, \\ Michael STURM ${ }^{2)}$, Willem O. VAN DER KNAAP ${ }^{1)}$ and Jacqueline F.N. VAN LEEUWEN ${ }^{1)}$ \\ ${ }^{1)}$ Laboratory of Paleobotany and Palynology, University of Utrecht, Budapestlaan 4, NL-3584 Utrecht, The Netherlands and \\ Geobotanical Institute, University of Bern, Altenbergrain 21, CH-3013 Bern, Switzerland \\ ${ }^{2}$ Swiss Federal Institute for Environmental Science and Technology (EAWAG), CH-8600 Dübendorf, Switzerland \\ ${ }^{3)}$ Max-Planck-Institut für Limnologie, Plön, Germany \\ ${ }^{4)}$ Österreichische Akademie der Wissenschaft, Mondsee, Austria \\ ${ }^{5} \mathrm{CNR}$, Istituto Italiano di Idrobiologia, Largo Tonolli 50, I-28922 Verbania-Pallanza, Italy \\ *e-mail corresponding author: A.Lotter@bio.uu.nl
}

\begin{abstract}
Several short sediment cores of between 35 and $40 \mathrm{~cm}$ from Hagelseewli, a small, remote lake in the Swiss Alps at an elevation of $2339 \mathrm{~m}$ a.s.l. were correlated according to their organic matter content. The sediments are characterized by organic silts and show in their uppermost part a surprisingly high amount of organic matter (30-35\%). Synchronous changes, occurring in pollen from snow-bed vegetation, the alga Pediastrum, chironomids, and grain-size composition, point to a climatic change interpreted as cooler or shorter summers that led to prolonged ice-cover on the lake. According to palynological results the sediments date back to at least the early $15^{\text {th }}$ century A.D., with the cooling phase encompassing the period between late $16^{\text {th }}$ and the mid-19 $9^{\text {th }}$ century thus coinciding with the Little Ice Age. Low concentrations of both chironomid head capsules and cladoceran remains in combination with results from fossil pigment analyses point to longer periods of bottom-water anoxia as a result of long-lasting ice-cover that prevented mixing of the water column. According to our results aquatic biota in Hagelseewli are mainly indirectly influenced by climate change. The duration of ice-cover on the lake controls the mixing of the water column as well as light-availability for phytoplankton blooms.
\end{abstract}

Key words: diatoms, pollen, chironomids, cladocera, chrysophyte cysts, grain-size analysis

\section{INTRODUCTION}

Traditionally, ecological work in mountain regions has concentrated either on extreme habitats for plant and animal life or on steep environmental gradients that create conspicuous ecotones such as the tree line. After the pioneering days of Alpine lake research, recent limnological studies in the Alps have concentrated mainly on the effect of acid atmospheric deposition on aquatic environments (Psenner \& Catalan 1994; Marchetto et al. 1994) or on the impact of increased ultraviolet radiation on biota (Sommaruga \& Garcia-Pichel 1999; Vinebrooke \& Leavitt 1996). Studies of alpine lake sediments are focussed mainly on climate change, albeit through palaeobotanical evidence for tree line fluctuations (Wick \& Tinner 1997) or the influence of glacial melt water on varve thickness (Leemann \& Niessen 1994).

Very few palaeolimnological studies combining the analysis of different biological and sedimentological proxies have been carried out in the Alps. This study is part of a Europe-wide attempt at a multi-proxy reconstruction of past climate change in mountain regions using standardized field and analytical methods within the framework of the European Union Environment and Climate project MOLAR (Measuring and Modelling the
Dynamic Response of Remote Mountain Lake Ecosystems to Environmental Change: a Program of Mountain Lake Research).

Whereas lowland lakes have been heavily influenced by anthropogenic action in their catchment over timescales from centuries to millennia, remote mountain lakes are thought to be pristine. Therefore, the signals archived in their sediments reflect mainly the direct and indirect effects of climate on the lakes and their catchment. Finding such untouched lakes with catchments that are not impacted by tourism or grazing has become very difficult in the Alps. Based on data from a survey of several lakes in the Alps (Müller et al. 1998) we decided to study Hagelseewli and its processes in the water column as well as its sediments.

\section{SITE}

Hagelseewli $\left(46^{\circ} 40^{\prime} \mathrm{N}, 8^{\circ} 02^{\prime} \mathrm{E}\right)$ is a hard-water lake located at $2339 \mathrm{~m}$ a.s.l. in a north-facing cirque in the Bernese Alps, Switzerland, about $400 \mathrm{~m}$ above presentday timber line. The lake basin is relatively deep (Fig. 1), having a maximum depth of $18.5 \mathrm{~m}$, but a surface area of only $24,000 \mathrm{~m}^{2}$. Screes, alpine meadows and snow-bed vegetation are the dominant cover in the catchment. Details of the catchment geology, presentday limnology and meteorology are given by (Ohlen- 
dorf et al. 2000, this issue). Ice-cover on the lake persists for at least nine months of the year; after some snow-rich winters and cool summers the lake may even remain ice-covered throughout the whole year (as, e.g., in 1947, 1981, 1987). Under ice-cover the water column becomes depleted in oxygen, and phosphorus dissolved from the sediments is available for algal growth after thawing (Goudsmit et al. 2000; Ohlendorf et al. 2000, this issue).

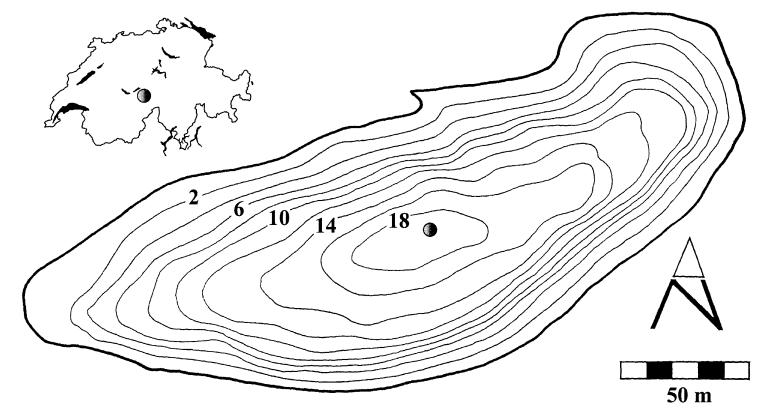

Fig. 1. Map of Switzerland showing the location of Hagelseewli and bathymetric map of the basin indicating the location of the cores. Depth intervals are in meters.

In May 1996 five short cores (HAG96-1 to HAG965) were taken in the deepest part of the basin with a Kajak corer (Renberg 1991) and extruded on site in contiguous $0.5-\mathrm{cm}$ steps into plastic bags. Samples were stored frozen before further processing. Water content and loss-on-ignition (LOI) at $550{ }^{\circ} \mathrm{C}$ was determined for all samples. Sediment chronology was established based on ${ }^{137} \mathrm{Cs}$ and ${ }^{210} \mathrm{~Pb}$ dating of two cores. Relatively uniform sedimentation rates fluctuating about a mean of $0.011 \pm 0.002 \mathrm{~g} \mathrm{~cm}^{-2} \mathrm{y}^{-1}$ were calculated throughout most of the past 150 years.

The top $7 \mathrm{~cm}$ of the core consists of black, homogenous, flocculent, sandy, clayey silts with a high organic content (Fig. 2). Between 7 and $38 \mathrm{~cm}$ the sediment consists of black, grey and brown, irregularly laminated, sandy, clayey silts with an organic content of around $10 \%$ (Fig. 3). The cores can be subdivided into $3 \mathrm{sec}-$ tions based on the LOI-data (Fig. 3). Values fluctuate around a mean of $7.7 \%$ in the lowermost section (6-38 $\mathrm{cm})$, then show a modest increase in the middle section $(2-6 \mathrm{~cm})$, and a sharp increase towards the sediment surface in the uppermost section $(0-2 \mathrm{~cm})$. Maximum LOIvalues of $30-35 \%$ were measured in Hagelseewli surface sediments, which are almost three times higher than for other, highly productive Swiss lakes. These high values are the result of low sedimentation rates in combination with low carbon mineralization as a result of low oxygen content at the water-sediment interface. Furthermore, Ohlendorf \& Sturm (in prep.) showed that calcite precipitated from the water column is dissolved at the water-sediment interface.

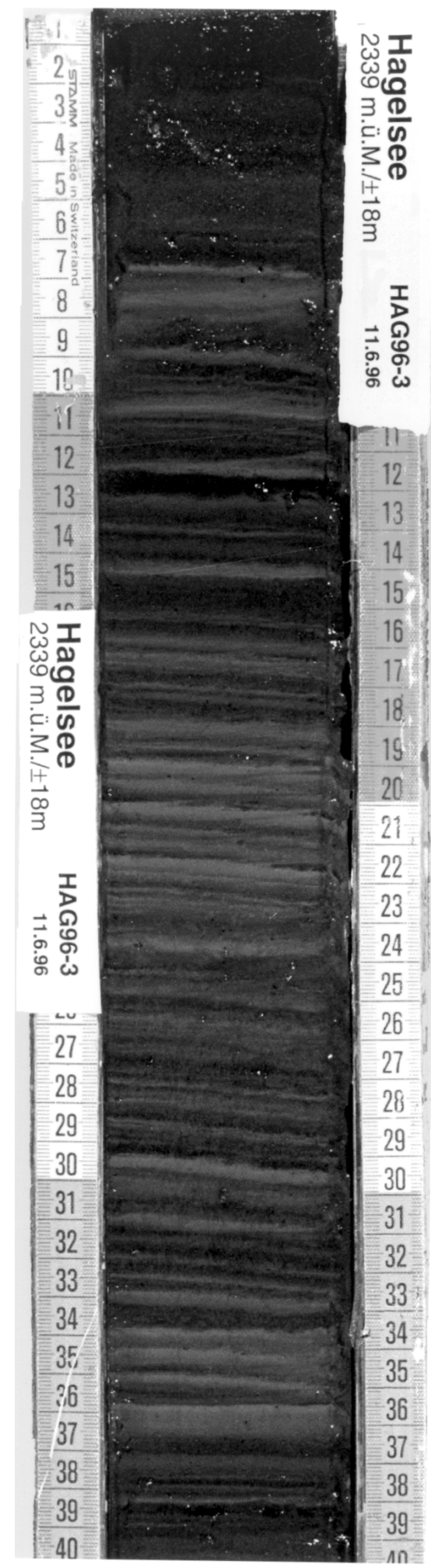

Fig. 2. Photograph of a short core taken at the deepest part of the Hagelseewli. Scale is in centimeters.

Correlation of cores HAG96-1 to HAG96-5 were carried out based on their LOI curves (Fig. 3). Curve matching was done with the program ANALYSERIES 


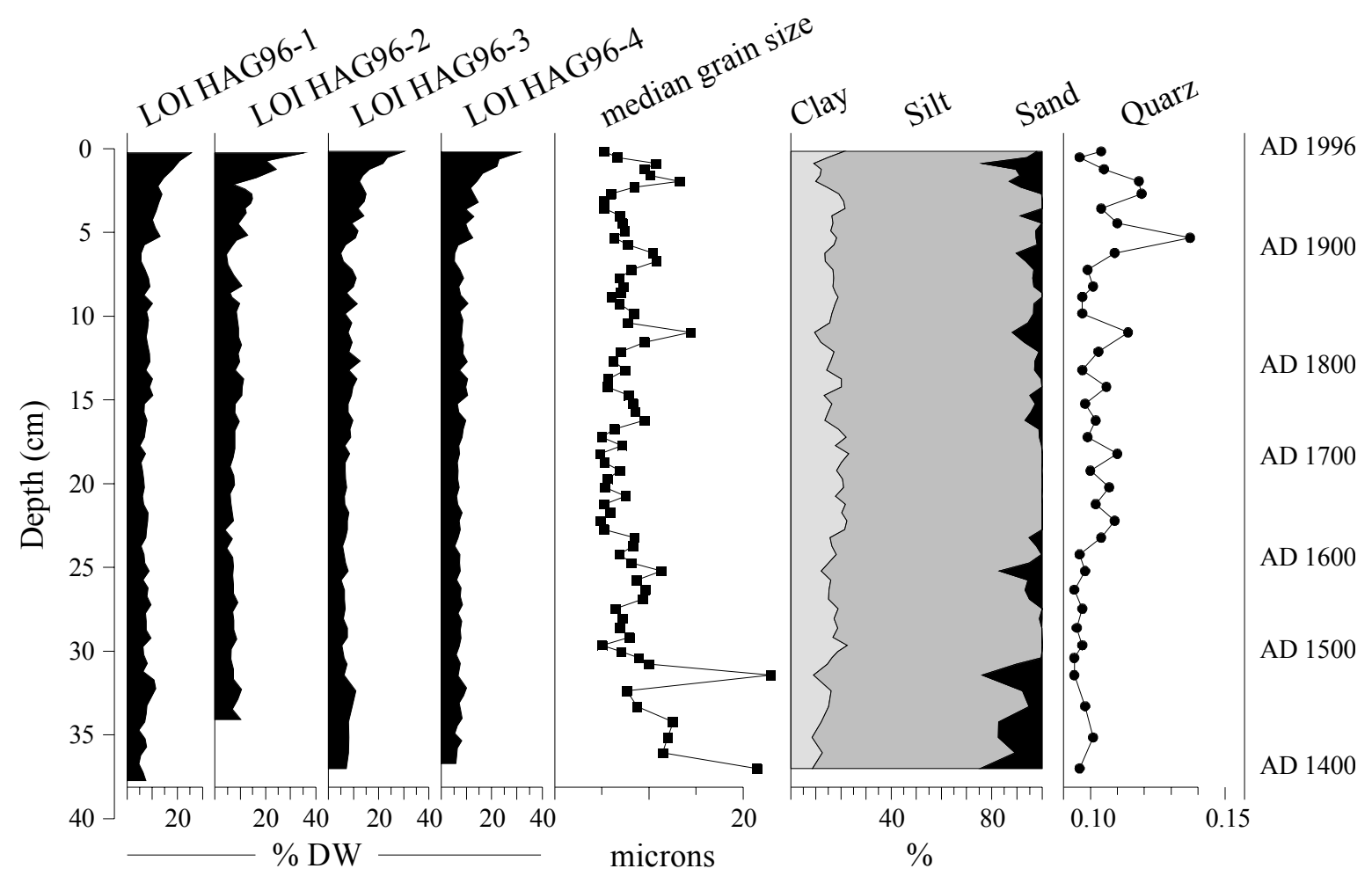

Fig. 3. Loss-on-ignition curves at $550^{\circ} \mathrm{C}$ of HAG96 cores $1-4$ expressed as percentage dry weight. Median grain size, grain size composition, and quartz in core HAG96-3. All data are expressed in standard depths of core HAG96-1.

(Paillard et al. 1996). Using HAG96-1 as master core, all sediment depths for cores HAG96-2 to HAG96-5 were then expressed as equivalent depths in HAG96-1. For reasons of better comparability all depth notations given in this contribution thus refer to the depths in the master core.

\section{SEDIMENT COMPOSITION AND GRAIN-SIZE DISTRIBUTION}

The mineral composition of sediment samples from core HAG96-3 was determined by X-ray diffraction (XRD) of smear slides. For smear slide preparation approx. $3 \mathrm{~mm}^{3}$ of sediment were suspended with acetone in a mortar and ground to $<63 \mu \mathrm{m}$. The suspension was then transferred to a glass sample holder were it slowly dried out. This procedure caused a preferred orientation of platy minerals that allowed their identification, even if only small quantities were present, by enhancing the base reflections. Diffraction patterns were recorded with a Scintag XDS 2000 at $45 \mathrm{kV}$ and $40 \mathrm{~mA}$ with $\mathrm{Cu} \mathrm{K \alpha}$ radiation between 2 and $70^{\circ} 2 \Theta$. The ratio of peak intensity of a given mineral and the total peak sum was used as a semi-quantitative measure for the concentration (Fanning et al. 1989).

A Laser-Particle-Analyzer, type Mastersizer, was used to determine the grain size distribution of the sediments $<150 \mu \mathrm{m}$ in core HAG96-3. For analysis 40 $\mathrm{mg}$ of the freeze dried sediment were filled into a centri- fuge tube and suspended in $10 \mathrm{ml}$ of a $15 \% \mathrm{H}_{2} \mathrm{O}_{2}$ solution at $40-45{ }^{\circ} \mathrm{C}$ for at least 48 hours to remove minor amounts of organic matter and to promote deflocculation. After that sediment samples were rinsed twice with distilled water and centrifuged at $4000 \mathrm{rpm}$. For measurements the sample was suspended in $3 \mathrm{ml} 0.01 \%$ Calgon solution.

The topmost $31 \mathrm{~cm}$ are relatively fine grained with a median grain size varying between 5 and $15 \mu \mathrm{m}$. Peak values in this section occur at $1-2 \mathrm{~cm}, 6-7 \mathrm{~cm}, 11 \mathrm{~cm}$ and $25 \mathrm{~cm}$ sediment depth. In these samples the sand fraction $(>63 \mu \mathrm{m})$ increases to values of up to $25 \%$. From $31 \mathrm{~cm}$ down to the bottom of the core the median grain size increases and reaches maximum values of 23 $\mu \mathrm{m}$. Sections with extraordinary low median values were detected at $2.5-4.0 \mathrm{~cm}, 17.0-23.0 \mathrm{~cm}$ and 27.0 $30.5 \mathrm{~cm}$. These sections are virtually free of sand.

Mineralogically, the sediments mainly consist of quartz and smaller amounts of chlorite, micas and feldspars. In the topmost $2 \mathrm{~cm}$ gypsum was also detected. In an X-ray diffractogram the intensity of the quartz-peak at $4.26 \AA$ normalised to the sum of all detected peaks is a semi quantitative measure of the quartz concentration in the sediment. From the bottom of the core to $24 \mathrm{~cm}$ as well as between 7 and $10 \mathrm{~cm}$ quartz concentrations are generally low, whereas they are higher and show larger fluctuations between 10 and $24 \mathrm{~cm}$. Fluctuations are highest between the sediment surface and $7 \mathrm{~cm}$, with maximum quartz concentrations occurring at $5.5 \mathrm{~cm}$. 


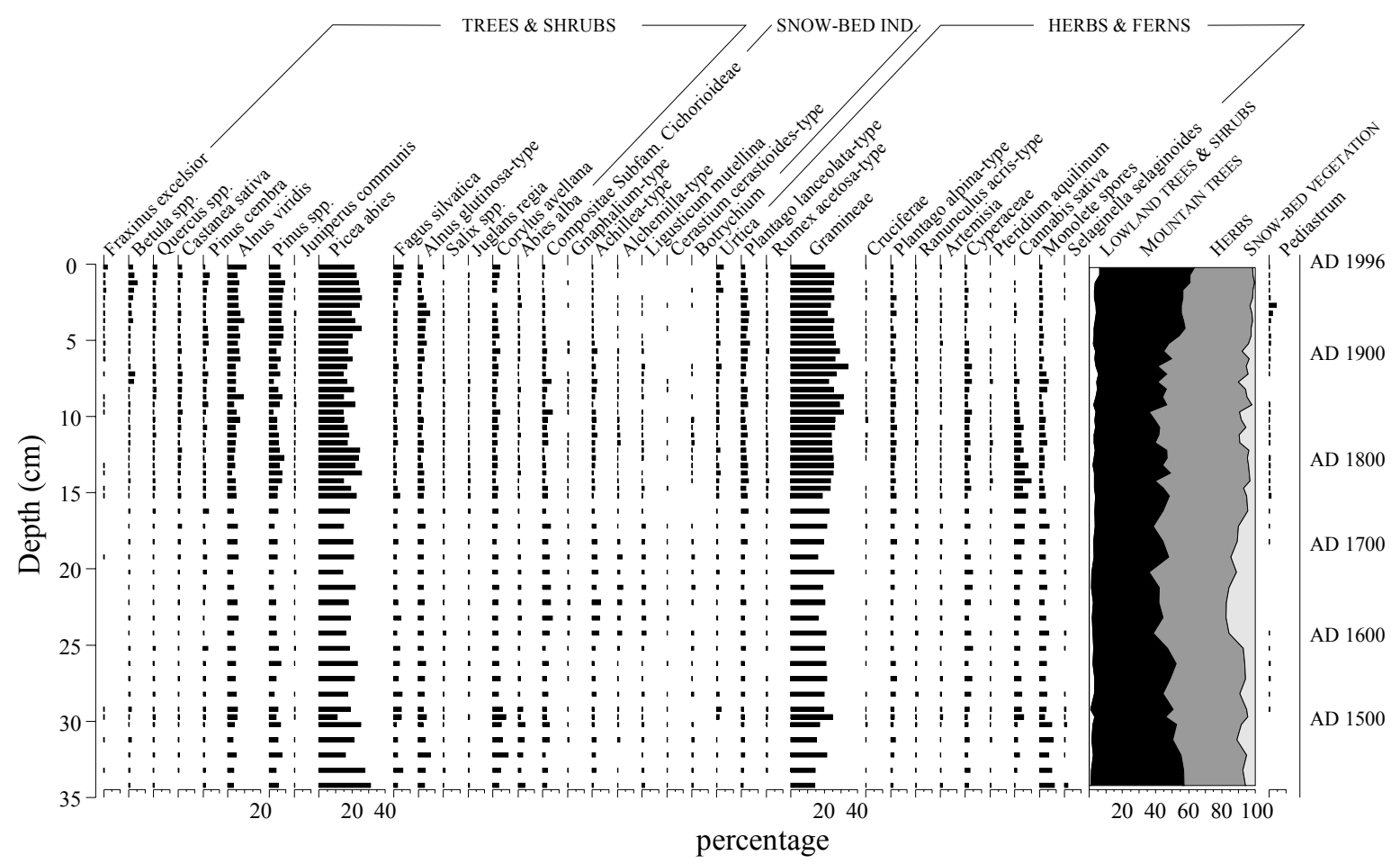

Fig. 4. Pollen diagram of core HAG96-1. Only selected taxa are shown.

Since the catchment of Hagelseewli consists almost exclusively of siliceous limestone, the composition of the detrital input does not vary much. Quartz is the dominant mineral in the sediments and small variations in its concentration reflect the degree of dissolution of other minerals (micas, chlorite, feldspars).

The grain size composition is controlled mainly by the grain size of the allochthonous mineral detritus, mainly quartz grains, and its amount relative to autochthonous particles, mainly diatoms that have a rather constant grain size between 10 and $20 \mu \mathrm{m}$. We believe that the grain size composition, especially the sand concentration is related to the status of ice cover on the lake. From recent observations it is known that the lake does not thaw completely during certain years. This reduces allochthonous input from the catchment and thus changes the grain size composition of the sediment. Accordingly, we interpret the three sections with a very low median grain size and the absence of sand as phases with strongly reduced detrital input due to an extended period of lake ice cover.

\section{BIOSTRATIGRAPHIES}

\subsection{Pollen}

A total of 51 samples were analysed for pollen in core HAG96-1 (van der Knaap et al. 2000). The samples were taken at $0.5 \mathrm{~cm}$ intervals and had a volume of $0.5 \mathrm{~cm}^{3}$ each. They were prepared using standard methods. The pollen assemblages are dominated by longdistance transported pollen from the montane belt, mainly Picea abies, but also to some extent Pinus and Alnus viridis. The vegetation of the alpine meadows in the catchment of the lake is underrepresented in the pollen assemblages. However, a special feature of this site is the abundance of snow-bed vegetation around the lake, which is well reflected in the pollen diagram.

Although the major part of the pollen assemblages, especially tree pollen, does not originate from the catchment of Hagelseewli, the pollen of snow-bed vegetation allows an interpretation in terms of past climatic change. Their increased occurrences between 25 and $16 \mathrm{~cm}$ (Fig. 4) together with the decline of several tree pollen taxa, was interpreted as a lowering of summer temperatures or shorter growing seasons by (van der Knaap et al. 2000), whereas the higher abundance of Pediastrum during periods of lower occurrences of snow-bed vegetation pollen would point to periods with warmer summers and thus longer ice-free periods.

\subsection{Diatoms}

Aliquots of all 74 samples of core HAG96-1 were treated with $10 \% \mathrm{HCl}, 30 \% \mathrm{H}_{2} \mathrm{O}_{2}$, and spiked with microspheres (Battarbee \& Kneen 1982) for diatom analyses. Diatom taxonomy follows (Krammer \& LangeBertalot 1986-1991). Between 300 and 400 valves were counted in each slide.

The diatom stratigraphy is mainly characterized by changes in the dominant taxa such as Cyclotella comensis, Thalassiosira pseudonana, Fragilaria pinnata, and F. parasitica (Fig. 5). 


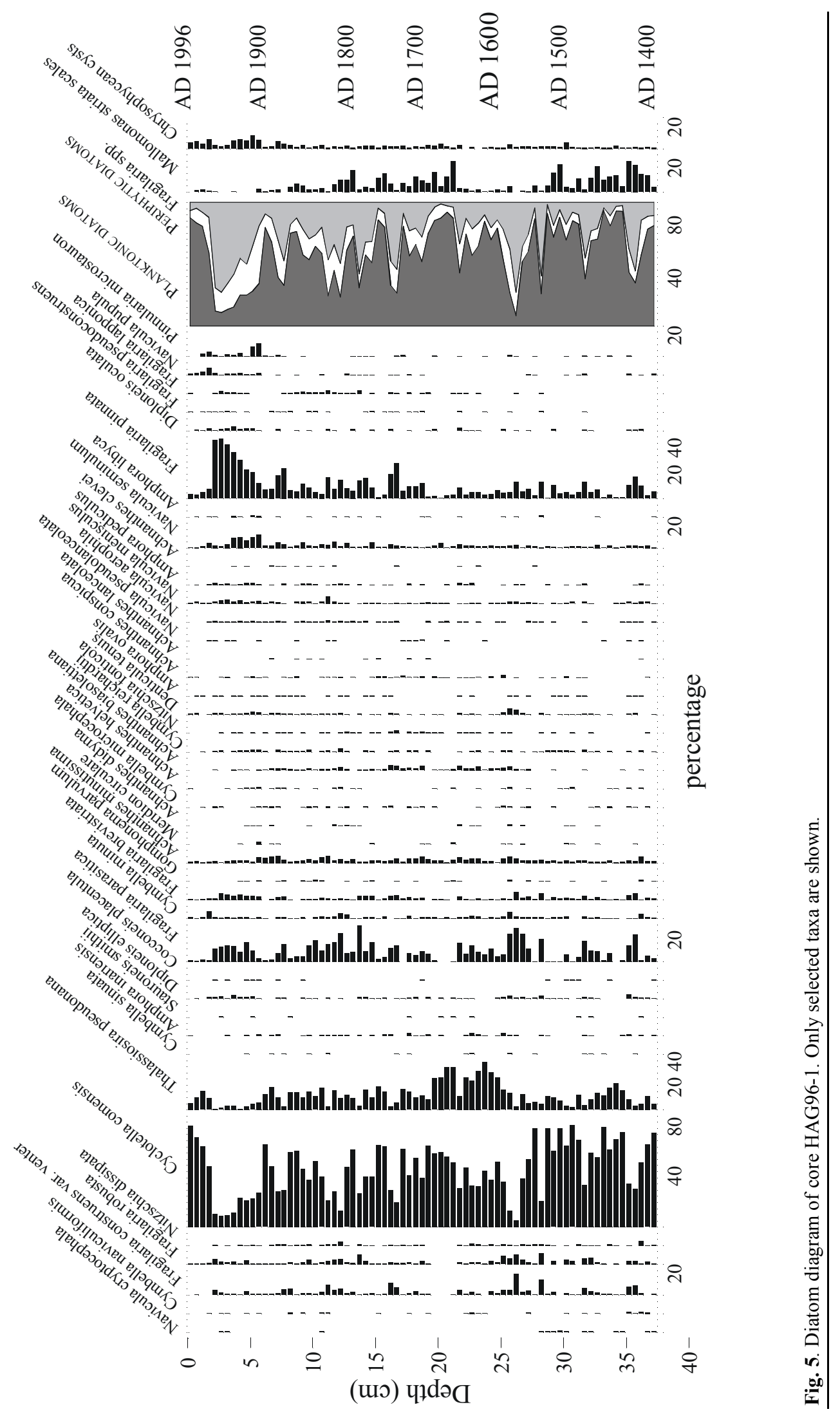


Diatom accumulation rates show that decreases in the relative abundance of Cyclotella are also related to decreases in their accumulation rates, whereas the Fragilaria accumulation rates stay more or less constant throughout the core (Lotter \& Bigler 2000). Fragilaria taxa are encountered mainly in the surficial sediments of the littoral zone of Hagelseewli (Lotter \& Bigler 2000; Ohlendorf et al. 2000, this issue). These become icefree some months before complete ice-break. Their presence in the deepest part of the basin is the result of sediment focussing and lateral water movement from the littoral, whereas Cyclotella blooms in the water column after ice break-up (Lotter \& Bigler 2000; Ohlendorf et al. 2000 this issue). Recently, Scheffler et al. (2000) showed that there are two morphs of Cyclotella pseudocomensis that bloom at different seasons. According to these observations it may be hypothesized that the small, ornamented Hagelseewli Cyclotella comensis and the hyaline Thalassiosira pseudonana, which is in the same size-class, could be morphs of the same taxon.

\subsection{Chrysophyte cysts}

The samples treated for diatom analysis from core HAG96-1 were also used to analyse the chrysophyte cyst stratigraphy. The cyst identification and their relative abundance were assessed using SEM analysis. In each sample at least 200 cysts were counted. Identification follows Duff et al. (1995), Facher \& Schmidt (1996), Vorobyova et al. (1996), Zeeb et al. (1996), Brown et al. (1997), Gilbert et al. (1997), van der Vijver \& Beyens (1997a, 1997b) and Wilkinson et al. (1997). Information about the different cysts and their ecology is given in table 1, and stomatocyst stratigraphy is shown in figure 6.

\subsection{Cladocera}

A standard procedure following Frey (1986) was used for the preparation of chironomid and cladoceran remains from core HAG96-4: the wet sediment samples were heated in $10 \% \mathrm{KOH}$ on a stirrer hot plate for about 10 minutes. After cooling the samples were screened through a $40 \mu \mathrm{m}$-sieve. For cladoceran analysis, subsamples of the fractions $>100 \mu \mathrm{m}$ and $40-100 \mu \mathrm{m}$ were counted separately under a microscope at $100 \times$ magnification. Ephippia of Daphnia were counted in the total samples under a stereomicroscope at $20 \times$ magnification. For identification the keys by Frey (1958) and Flössner (1972) were used, whereas taxonomy follows Flössner (1972).

Despite rather large samples (0.5-6.0 g wet weight) the cladoceran numbers counted were extremely low. In total, 1539.5 cladoceran remains were counted, of which shells of Chydorus sphaericus (83.1\%) and post-abdominal claws of Daphnia pulex group (15.6\%) made up $98.7 \%$. Besides the overall dominance of $C$. sphaericus, only four other chydorids were found: Camptocer- cus rectirostris (0.5 specimen), Alona quadrangularis (2), Leydigia quadrangularis (0.5), and Alonella excisa (1). Based on the concentrations of $C$. sphaericus the core can be divided into two sections, with a distinct boundary around $25 \mathrm{~cm}$. In the lower section, there was considerable variation in the concentrations, whereas above $25 \mathrm{~cm}$ concentrations were clearly lower.

The planktonic cladocerans were almost exclusively represented by ephippia and claws of the Daphnia pulex group (93.6\%), with only single findings of Bosmina longirostris (15 specimens) and Bosmina spec. (1.5). The data clearly show that densities of Daphnia ephippia were in general higher than densities of post-abdominal claws, and ephippia were also found in the sediment sections where no claws were present (Fig. 7) which indicates that the claws were not quantitatively preserved in the sediment.

As shown by the modern Alpine cladoceran training set (Lotter et al. 1997), Bosmina species do not frequently occur in the lakes above $1800 \mathrm{~m}$ altitude. Therefore, in most cases Daphnia is the only planktonic taxon that is represented in the sediment, as is the case in Hagelseewli. With respect to the chydorids, there is strong predominance of a single species in many high altitude lakes, such as Alona quadrangularis, A. rectangula, Acroperus harpae, and most frequently $C$. sphaericus. The latter species was not only predominant in the surface sediment of Hagelseewli but also in many other subalpine and alpine lakes (Lotter et al. 1997). In the case of Hagelseewli, the extremely low species diversity manifested by the almost exclusive occurrence of one benthic ( $C$. sphaericus) and one planktonic taxon ( $D$. pulex group) does not only reflect the high altitude of the lake but also the particular local situation with shading and low summer water temperature as well as a long period of ice cover (see Ohlendorf et al. 2000, this issue).

\subsection{Chironomids}

For chironomid analysis the sediment fractions $>200$ $\mu \mathrm{m}$ and 100-200 $\mu \mathrm{m}$ of core HAG96-4 were examined under a stereomicroscope at $20 \times$ magnification. The head capsules were picked out and mounted on permanent slides (Hofmann 1986). For identification the keys by Wiederholm (1983) and Schmid (1993) were used.

In the 100-200 $\mu \mathrm{m}$ fraction, two types of small head capsules were found which are most likely to represent the first larval stages of Pseudodiamesa and Diamesa. Three male hypopygia of the genus Micropsectra were found which were identified as $M$. borealis.

Chironomid density varied from 0.2 to 28 specimens $\mathrm{g}^{-1}$ wet sediment. In total, the chironomid analysis provided 3308.5 head capsules from 12 taxa and several not identified specimens of the Orthocladiinae. Micropsectra (64\%) and Pseudodiamesa (24\%) made up $88 \%$ of the chironomid assemblages. Other frequent taxa were Diamesa (4.1\%), Orthocladius (4.0\%), and Heterotris- 
Tab. 1. Chrysophyte stomatocyst found in Hagelseewli core HAG96-1 and their taxonomical and ecological relationship to similar taxa found by other authors.

\begin{tabular}{|c|c|c|}
\hline Cyst & Description & Ecology \\
\hline 1 & cf. \# 167 (Duff et al. 1995) & $\begin{array}{l}\text { As a member of a collective category, this stomatocyst was most } \\
\text { common in large, acidic to circumneutral lakes } \\
\text { (Duff et al. 1995). }\end{array}$ \\
\hline 2 & $\begin{array}{l}\text { Stomatocyst of Mallomonas striata (Asmund \& } \\
\text { Kristiansen 1986) }\end{array}$ & $\begin{array}{l}\text { Ecology of stomatocyst unknown. } \\
\text { Trophic preferences of vegetative cells: in New England lakes this } \\
\text { taxon was found in mesotrophic lakes (TP: } 10-25 \mu \mathrm{g} \mathrm{l}^{-1} \text {; TN: } 200- \\
500 \mu \mathrm{g}^{-1} \text {; Chlorophyll- } a \text { : } 2-10 \mu \mathrm{g}^{-1} \text {; Secchi disk depth: } 3-6 \mathrm{~m} \text { ). } \\
\text { Optima: TP } \sim 22.5 \mu \mathrm{g} \mathrm{l}^{-1} \text {; TN } \sim 300 \mu \mathrm{g} \mathrm{l}^{-1} \text {; Chl a } \sim 2.5 \mu \mathrm{g} \mathrm{l}^{-1} \text {; Secchi } \\
\text { disk depth } \sim 4.2 \mathrm{~m} \text { (Siver \& Marsicano 1996). }\end{array}$ \\
\hline
\end{tabular}

$5 \quad$ Unpublished

$6 \quad$ No 81 (Facher \& Schmidt 1996)

cf. immature stage of \# 223 (Duff et al. 1995)

8 Unpublished

$9 \quad$ \# 33 (Duff et al. 1995)

Slightly acid to acid, alpine to high alpine lakes (Facher \& Schmidt 1996) small, deep, oligotrophic, low conductivity, mountain lakes (Duff \& Smol 1995; Duff et al. 1995).

This cyst may be produced by a cold-water taxon (Rybak 1986; Duff $\&$ Smol 1989), with a wide $\mathrm{pH}$ tolerance (Duff et al. 1995). It decreased in relative abundance after high nutrient loadings (Zeeb et al. 1994) and displayed a significant negative correlation with total phosphorus. It was particularly common in deep lakes (Duff et al. 1995). In the Yukon and Northwest Territories it was found at low temperatures and particulate nitrogen and relatively high DIC concentrations (Brown et al. 1997). Duff \& Smol (1995) associated it with high altitude lakes.

12 cf. \# 205, but slightly smaller (Duff et al. 1995) This stomatocyst is probably produced by an alkaliphilous species (Rybak et al. 1991) tolerant of high conductivities.

15 No 2 (Facher \& Schmidt 1996) \# 9 (Duff et al. 1995)

This stomatocyst appears to be tolerant of a wide range of environmental variables (Brown et al. 1997) including pH (Duff \& Smol 1988; Duff et al. 1992; Carney et al. 1992), temperature (Duff \& Smol 1988; Duff et al. 1992; Carney et al. 1992), and salinity (Pienitz et al. 1992). It displayed a negative correlation with Secchi depth (Duff et al. 1995).

17 cf. \# 173, but somewhat smaller (Duff et al. 1995) Preference for slightly acid, high alpine lakes (Facher \& Schmidt 1996). Slightly acid to neutral high alpine lakes (Facher \& Schmidt 1996)

18 No 5 (Facher \& Schmidt 1996) \# 120 (Duff et al. 1995) This cyst was primarily found in circumneutral to alkaline water (Duff et al. 1992; Rybak et al. 1987). It increased in relative abundance after nutrient additions (Zeeb et al. 1994). It was positively correlated with total phosphorus in freshwater British Columbia lakes (Duff et al. 1995). It was found in eutrophic, alkaline, generally shallow lakes high in conductivity (Duff \& Smol 1995).

Throughout the core, the chironomid fauna is characterised (1) by low species diversity, (2) by the total absence of taxa from the subfamily Tanypodinae and the tribe Chironomini, and (3) by the predominance of Diamesinae and Orthocladiinae. Thus, the assemblage reflects extreme ecological conditions such as the temperature regime of this site. This is in accordance with the occurrence of Micropsectra borealis, first described from Novaya Zemlya and was so far known only from the alpine region of North Europe (Säwedal \& Willassen 1980).

As shown by the modern Alpine training set, the chironomid fauna of Hagelseewli is remarkable, even among the lakes above $2000 \mathrm{~m}$ a.s.l., because of the ex- 


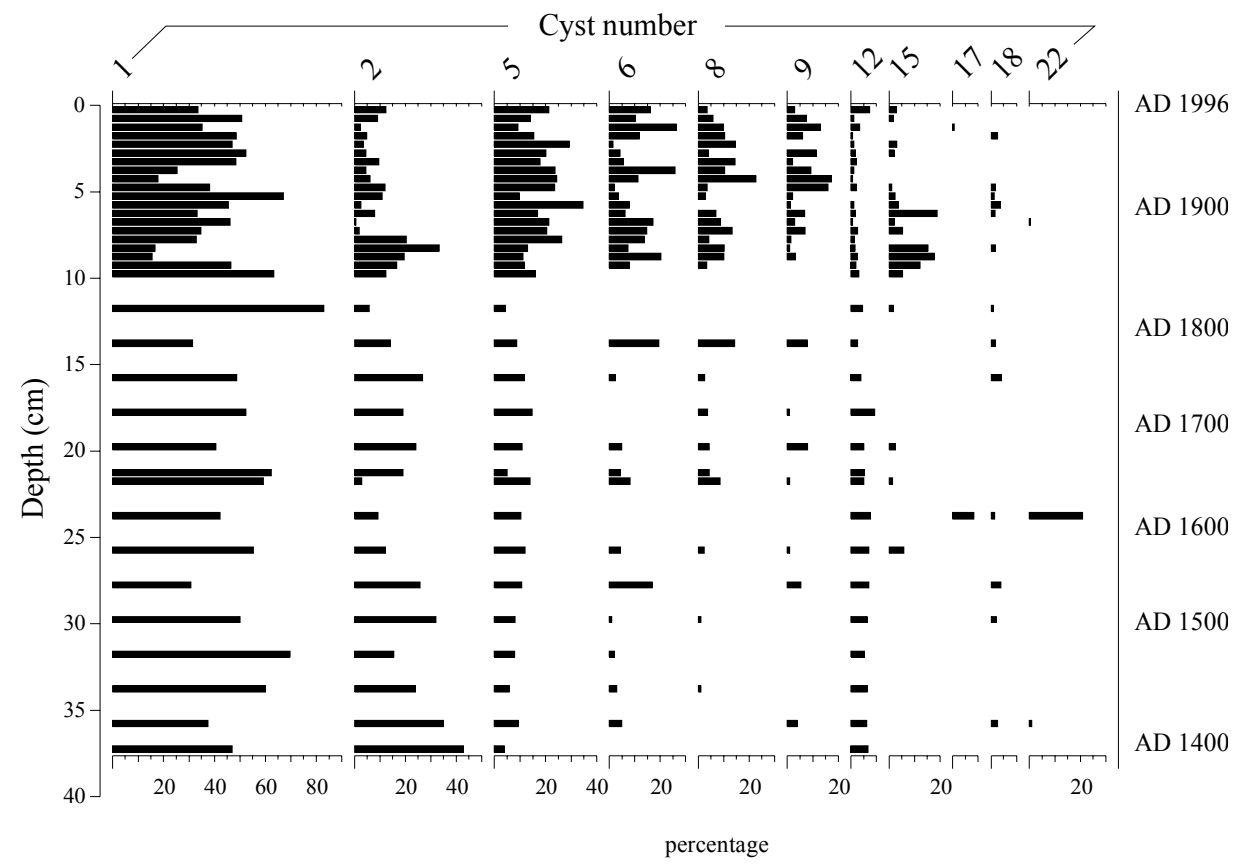

Fig. 6. Chrysophyte cyst diagram of core HAG96-1.

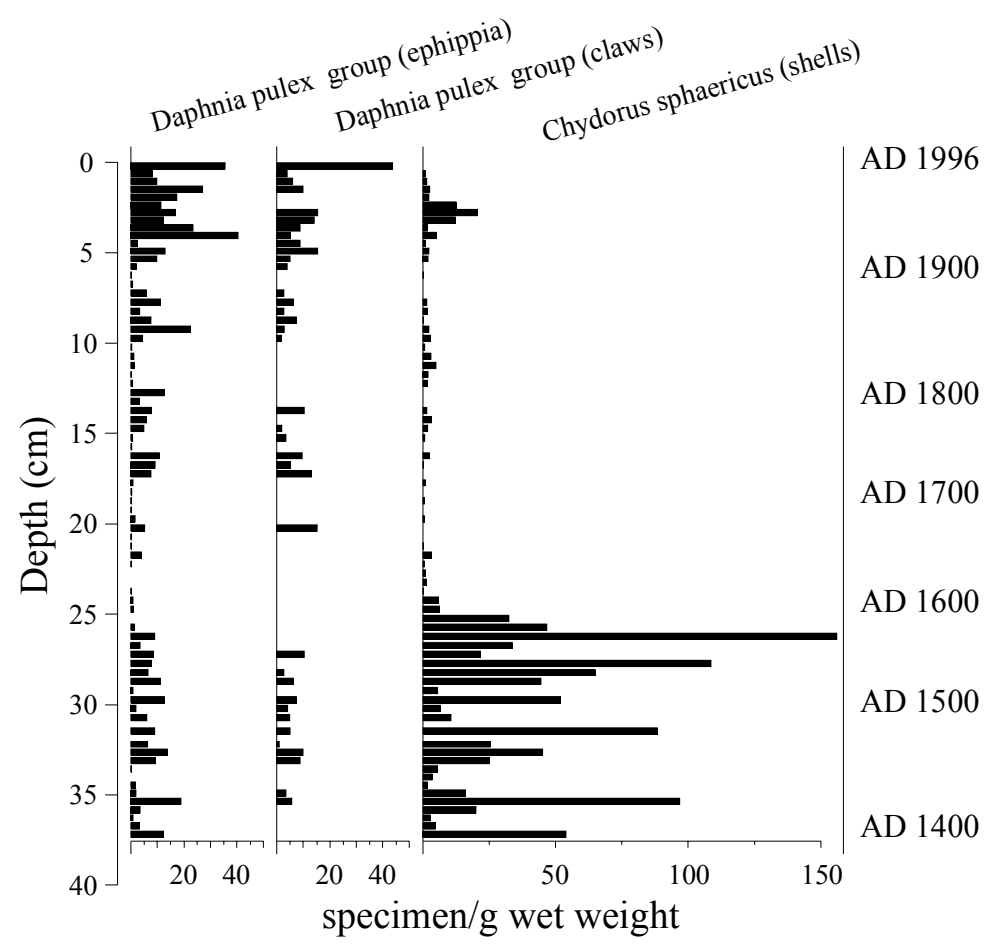

Fig. 7. Cladoceran concentration in core HAG96-4. The depth refers to standard depth in core HAG96-1.

tremely low number of species and as a result of the combination of predominant species, e. g. Micropsectra and Pseudodiamesa. In the other six lakes from this altitude, Micropsectra is also generally dominant, but elsewhere it is combined with other taxa like Psectrocladius, Eukiefferiella, Heterotrissocladius, Tanytarsus gr. lugens, or Paracladius (Lotter et al. 1997).

\subsection{Algal and bacterial carotenoid stratigraphy}

Plant pigment analyses were performed in core HAG96-2. A subsample of $0.5 \mathrm{~g}$ wet weight was extracted overnight with $90 \%$ acetone, centrifuged at 4000 rpm for 10 minutes and the supernatant used for HPLC chromatographic analyses following the methodology 


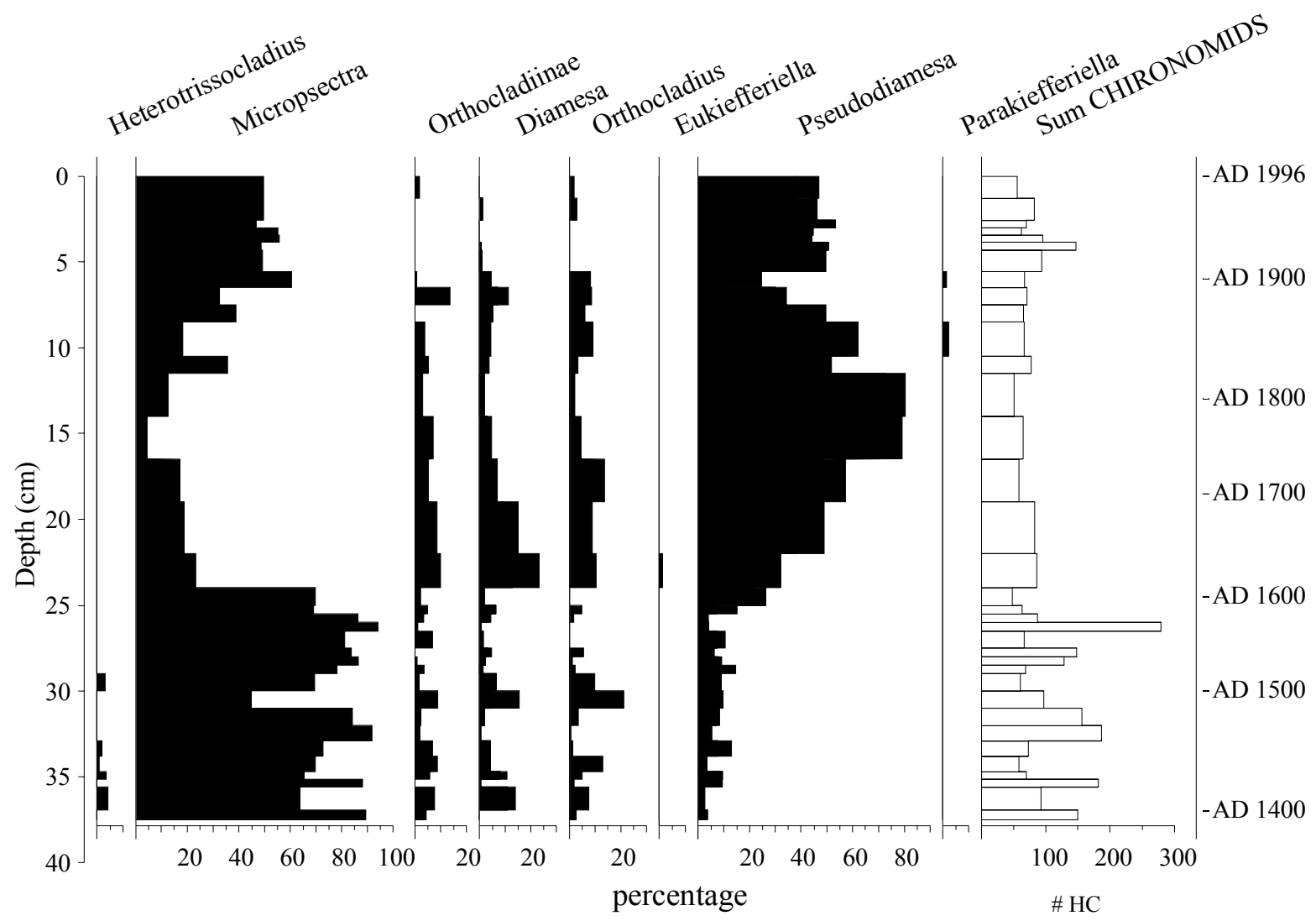

Fig. 8. Chironomid diagram of core HAG96-4. The depth refers to standard depth in core HAG96-1.

described in Lami et al. (2000, this issue). A summary of the main carotenoids identified is reported in figure 9 .

The carotenoid profiles show three zones $(0-4 \mathrm{~cm}, 8$ $15 \mathrm{~cm}$, and $25-35 \mathrm{~cm}$ ) where the pigment concentrations are generally higher. The lowest values are observed in the $17-25 \mathrm{~cm}$ section that corresponds to the period where all the proxies indicate a cold period. Here, there is also a clear reduction in carotenoids from sulphur photosynthetic bacteria. This is probably due to the very thick ice cover attenuating photosynthetically active radiation.

Isorenieratene, derived from green sulphur photosynthetic bacteria, is well represented throughout the whole core, while okenone, derived from purple sulphur photosynthetic bacteria, appears above $25 \mathrm{~cm}$. Their presence and especially okenone, have been associated with strong water column stratification or meromictic conditions. Bottom water anoxia is usually inferred from the presence of these carotenoids (Züllig 1985). Oxygen depletion in the water column of Hagelseewli was also demonstrated by Ohlendorf et al. (2000, this issue).

During the cold period where it is probable that year-round ice-cover was present on the lake surface, algal and bacteria carotenoids show lower concentrations, indicating that light limitation was likely to have reduced primary production during this period.

\section{DISCUSSION}

Establishing a reliable chronology for sediments from lakes above tree line is a major challenge because of the absence or sparseness of terrestrial plant remains that may be used for radiocarbon dating. Linear extrapolation of the accumulation rates as assessed by ${ }^{210} \mathrm{~Pb}$ dating of the uppermost sediments results in a basal age of about A.D. 1100 for the short sediment cores. However, given the conspicuous lithological change at 7 $\mathrm{cm}$ (Fig. 2), the fluctuations in the grain-size composition and the LOI curve (Fig. 3) it is likely that the accumulation rates in the lower part of the cores were higher. Moreover, van der Knaap et al. (2000), relying on palynological results dated the base of the core to the early $15^{\text {th }}$ century, which seems more realistic. A chronology based on this age is, therefore, adopted for the further discussion.

Comparison of the changes in the different proxies shows in general a consistent picture. The major changes in pollen assemblages, as manifested by an increase in snow-bed indicators and interpreted as a climatic change towards either cooler or shorter summers started in the late $16^{\text {th }}$ century and lasted until about the early $18^{\text {th }}$ century. In the water column the absence of Pediastrum during the same period may indicate a longer annual period of ice-cover on Hagelseewli. This 


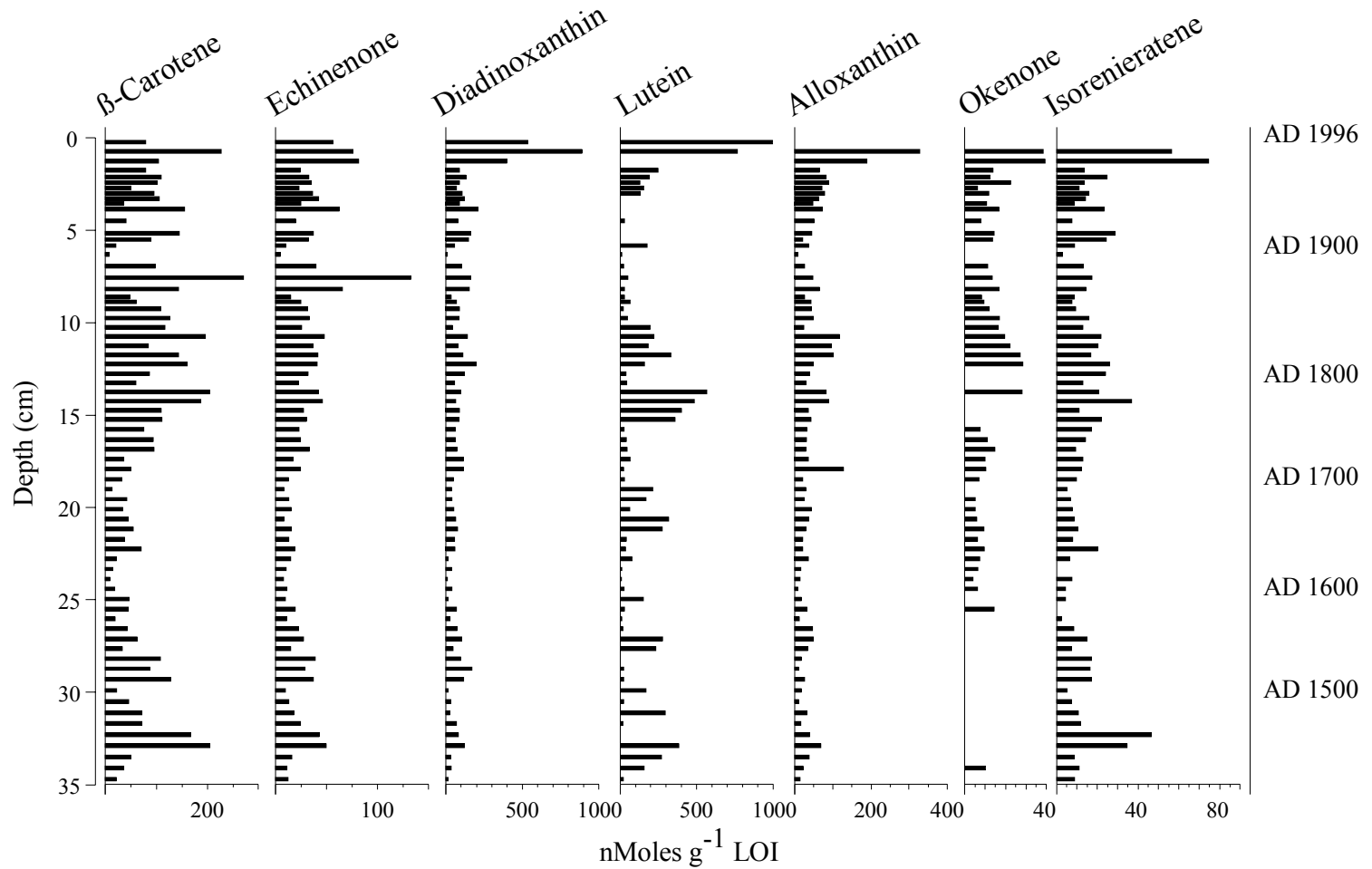

Fig. 9. Algal and bacterial carotenoid concentrations in core HAG96-2. The depth refers to standard depth in core HAG96-1.

interpretation is corroborated by the absence of sand during the mid- $17^{\text {th }}$ until the early $18^{\text {th }}$ century, also pointing to long ice-cover on the lake. The chironomid record is dominated by cold-indicating taxa as would be expected at this altitude. The change in dominance from Micropsectra to Pseudodiamesa is attributed to the time between the $17^{\text {th }}$ and the mid- $19^{\text {th }}$ century. This period is generally considered as the Little Ice Age in the Alps. Spring temperatures were below average between the mid $16^{\text {th }}$ century and the 1940 s, especially during the Maunder Minimum (ca 1690-1720, Pfister 1985). Summer temperatures, on the other hand, were warmer than today during the $18^{\text {th }}$ century and colder during the $19^{\text {th }}$ century until the 1930 s. According to Pfister (1985) autumn temperatures were generally colder between the onset of the $18^{\text {th }}$ century and the early 1920s. Such changes in the climate regime may influence the biology of Hagelseewli through the duration of ice cover on the lake. Prolonged ice-cover favours bottom-water anoxia (Ohlendorf et al. 2000, this issue) thus reducing the available space for oxygen-dependent organisms such as cladocera and chironomids. Furthermore, light penetration into the water column is inhibited by ice-cover, thus reducing the growth of algae and photosynthetic bacteria.

Since about the $17^{\text {th }}$ century higher concentrations of sulphur as well as the occurrence of pigments of anaerobic purple and green sulphur photosynthetic bacteria in the sediments imply strong water column stratification. It is also possible that meromictic conditions occurred with long periods of anoxic bottom water but thinner ice-cover or melting in the littoral area that would have allowed more light-penetration to the water column. The low abundances of benthic taxa such as the major chydorid taxon, C. sphaericus (Fig. 7) as well as the low chironomid abundances between the $17^{\text {th }}$ and the early $20^{\text {th }}$ century (Fig. 8) corroborate the existence of such meromictic conditions. In addition, prolonged ice-cover inhibits the life cycle of planktonic organisms and favours littoral benthic organisms that can develop as soon as the lake starts thawing and a marginal moat is formed (Smol et al. 1991). According to sediment-trap data (Ohlendorf et al. 2000, this issue; Lotter \& Bigler 2000) planktonic diatoms are light-limited by ice cover. Littoral Fragilaria taxa are transported to the centre of the lake by sediment focussing and lateral water movement. From these results, as well as the observations made in the arctic (Smol 1988; Douglas \& Smol 1999), it is hypothesised that the ratio of planktonic diatoms to Fragilaria species at this altitude reflects changes in duration of ice-cover. The number and abundance of Fragilaria taxa increased especially since the late $16^{\text {th }}$ century. Once again, the coincidence of elevated Fragilaria abundances with the lower spring temperatures between the mid $16^{\text {th }}$ century and the 1940 s may be the result of longer ice-cover on Hagelseewli, thus reducing the planktonic diatom standing crop. Lotter \& Bigler (2000) showed that the highest, statistically significant amount of variance in the Hagelseewli downcore diatom data is explained by winter precipitation and concluded that the amount of snow on the lake influences the duration of ice-cover and thus also the light 
regime for planktonic algae. The analyses of different biostratigraphies and sedimentological parameters from Hagelseewli support the findings evidenced by the data collected during a three-year water column-monitoring period at Hagelseewli (Ohlendorf et al. 2000, this issue). As the lake is decoupled from the atmospheric signal for the major part of the year, climate change has only an indirect effect on the formation of the sediment archive via the duration of ice-cover.

\section{ACKNOWLEDGMENTS}

We wish to thank the following persons: J. Bonderer, C. Meile, M. Wehrli, and A. Zwyssig, for their help during field work, I. Holderegger, P. Inauen and M. Winter for their lab assistance, and Dr. F. Reiss (Zoologische Staatssammlung, Munich) for the identification of subfossil chironomid male hypopygia (Micropsectra borealis). Dr. N.G. Cameron is acknowledged for helpful comments on the manuscript. Funding was provided by the Swiss Federal Office of Education and Science (Grant No. 95.0518-1) within the framework of the European Union Environment and Climate project MOLAR ('Measuring and Modelling the Dynamic Response of Remote Mountain Lake Ecosystems to Environmental Change: a Program of Mountain Lake Research'; Contract No. ENV4-CT95-007) as well as by the Swiss Priority Programme Environment (grant 5001-44600).

\section{REFERENCES}

Asmund, B. \& J. Kristiansen. 1986. The genus Mallomonas (Chrysophyceae). Opera Botanica, 85: 1-128.

Battarbee, R.W. \& M.J. Kneen. 1982. The use of electronically counted microspheres in absolute diatom ananalysis. Limnol. Oceanogr., 27: 184-188.

Brown, K.M., B.A. Zeeb, J.P. Smol \& R. Pienitz. 1997. Taxonomic and ecological characterization of chrysophyte stomatocysts from northwestern Canada. Can. J. Bot., 75: 842-863.

Carney, H.J., M.C. Whiting, K.E. Duff \& D.R. Whitehead. 1992. Chrysophycean cysts in Sierra Nevada (California) lake sediments: paleoecological potential. J. Paleolimnol., 7: 73-94.

Douglas, M.S.V. \& J.P. Smol. 1999. Freshwater diatoms as indicators of environmental change in the High Arctic. In: E.F. Stoermer \& J.P. Smol (Eds), The diatoms: application for the environmental and earth sciences. Cambridge, Cambridge University Press: 227-244.

Duff, K.E. \& J.P. Smol. 1988. Chrysophycean stomatocysts from the postglacial sediments of a High Arctic lake. Can. J. Bot., 66: 1117-1128.

Duff, K.E. \& J.P. Smol. 1989. Morphological description and stratigraphic distributions of the chrysophycean stomatocysts from a recently acidified lake (Adirondack Park, N.Y.). J. Palaeolimnol., 5: 73-113.

Duff, K.E., M.S.V. Douglas \& J.P. Smol. 1992. Chrysophyte cysts in 36 Canadian high arctic ponds. Nordic Journal of Botany, 12: 471-499.

Duff, K.E. \& J.P. Smol. 1995. The relationship of chrysophycean stomatocysts to environmental variables in freshwater British Columbian lakes. Can. J. Bot., 73: 1097-1111.

Duff, K.E., B.A. Zeeb \& J.P. Smol. 1995. Atlas of chrysophycean cysts. Kluwer, Dordrecht.
Facher, E. \& R. Schmidt. 1996. A siliceous chrysophycean cyst-based $\mathrm{pH}$ transfer function for Central European lakes. J. Paleolimnol., 16: 275-321.

Fanning, D.S., V.Z. Keramidas \& M. El-Desoky. 1989. Micas. In: J.B. Dixon \& S.B. Weed (Eds), Minerals in Soil Environments. Madison, Wisconsin, Soil Sciences of America: 551-634.

Flössner, D. 1972. Kiemen- und Blattfüsser, Branchiopoda, Fischläuse, Branchiura. Tierwelt Deutschlands, 60: 1-499.

Frey, D.G. 1958. The late-glacial cladoceran fauna of a small lake. Arch. Hydrobiol., 54: 209-275.

Frey, D.G. 1986. Cladocera analysis. In: B.E. Berglund (Ed.), Handbook of Holocene Palaeoecology and Palaeohydrology. Chichester, John Wiley \& Sons: 667-692.

Gilbert, S., B.A. Zeeb \& J.P. Smol. 1997. Chrysophyte stomatocyst flora from a forest peat core in the Lena River region, northeastern Siberia. Nova Hedwigia Beiheft, 64: 311-352.

Goudsmit, G.-H., G. Lemcke, D.M. Livingstone, A.F. Lotter, B. Müller \& M. Sturm. (2000). Hagelseewli: a fascinating high mountain lake - suitable for palaeoclimatic studies? Verh. int. Ver. Limnol., 27: in press.

Hofmann, W. 1986. Chironomid analysis. In: B.E. Berglund (Ed.), Handbook of Holocene Palaeoecology and Palaeohydrology. Chichester, John Wiley \& Sons: 715-727.

Krammer, K. \& H. Lange-Bertalot. 1986-1991. Bacillariophyceae. G. Fischer Verlag, Stuttgart.

Lami, A., P. Guilizzoni \& A. Marchetto. 2000. High resolution analysis of fossil pigments, carbon, nitrogen and sulphur in the sediment of eight European alpine lakes: the MOLAR project. In: A. Lami, N. Cameron \& A. Korhola (Eds), Paleolimnology and ecosystem dynamics at remote European Alpine lakes. J. Limnol., 59 (Suppl. 1): $15-28$.

Leemann, A. \& F. Niessen. 1994. Holocene glacial activity and climatic variations in the Swiss Alps: reconstructing a continuous record from proglacial lake sediments. The Holocene, 4: 259-268.

Lotter, A.F., H.J.B. Birks, W. Hofmann \& A. Marchetto. 1997. Modern diatom, cladocera, chironomid, and chrysophyte cyst assemblages as quantitative indicators for the reconstruction of past environmental conditions in the Alps. I. Climate. J. Paleolimnol., 18: 395-420.

Lotter, A.F. \& C. Bigler. (2000). Do diatoms in the Swiss Alps reflect the length of ice-cover? Aquat. Sci., 62: in press.

Marchetto, A., A. Barbieri, R. Mosello \& G.A. Tartari. 1994. Acidification and weathering processes in high mountain lakes in southern Alps. Hydrobiologia, 274: 75-81.

Müller, B., A.F. Lotter, M. Sturm \& A. Ammann. 1998. The influence of catchment quality and altitude on the water and sediment composition of 68 small lakes in Central Europe. Aquat. Sci., 60: 316-337.

Ohlendorf, C., C. Bigler, G.-H. Goudsmit, G. Lemcke, D.M. Livingstone, A.F. Lotter, B. Müller \& M. Sturm. 2000. Causes and effects of long periods of ice cover on a remote high Alpine lake. In: A. Lami, N. Cameron \& A. Korhola (Eds), Paleolimnology and ecosystem dynamics at remote European Alpine lakes. J. Limnol., 59 (Suppl. 1): $65-80$.

Paillard, D., L. Labeyrie \& P. Yiou. 1996. MacIntosh program performs time-series analysis. EOS, 77: 379.

Pfister, C. 1985. Das Klima der Schweiz von 1525 bis 1860. Geographica Helvetica, 4: 230-232.

Pienitz, R., I.R. Walker, B.A. Zeeb, J.P. Smol \& P.R. Leavitt. 1992. Biomonitoring past salinity changes in an athalassic subarctic lake. International Journal of Salt Lake Research, 1: 91-123.

Psenner, R. \& J. Catalan. 1994. Chemical composition of lakes in crystalline basins: a combination of atmospheric deposition, geologic background, biological activity and human action. In: R. Margalef (Ed.), Limnology Now: A 
Paradigm of Planetary Problems. Elsevier Science B.V.: 255-314.

Renberg, I. 1991. The HON-Kajak sediment corer. J. Paleolimnol., 6: 167-170.

Rybak, M. 1986. The chrysophycean paleocyst flora of the bottom sediments of Kortowskie lake (Poland) and its ecological significance. Hydrobiologia, 140: 67-84.

Rybak, M., I. Rybak \& M. Dickman. 1987. Fossil chryophycean cyst flora in a small meromictic lake in soutern Ontario, and its paleoecological interpretation. Can. J. Bot., 65: 2525-2540.

Rybak, M., I. Rybak \& K. Nicholls. 1991. Sedimentary chrysophycean cyst assemblages as paleoindicators in acid sensitive lakes. J. Paleolimnol., 5: 19-72.

Säwedal, L. \& E. Willassen. 1980. Redescription of Micropsectra borealis (Kiefer, 1922) n. comb. (Diptera: Chironomidae). Ent. scand. Suppl., 11: 56-60.

Scheffler, W., A. Nicklisch \& D. Hepperle. 2000. Dimorphismus bei Cyclotella pseudocomensis (Bacillariphytceae Centrales). Abstract 14. Deutschsprachige Diatomologen Tagung, Bern.

Schmid, P.E. 1993. A key to the larval Chironomidae and their instars from Austrian Danube region stream and rivers. Part 1, Diamesinae, Prodiamesinae and Orthocladiinae. Wasser und Abwasser Suppl., 3: 1-514.

Siver, P.A. \& L.J. Marsicano. 1996. Inferring lake tropic status using scaled chrysophytes. Beiheft zur Nova Hedwigia, 114: 233-246.

Smol, J.P. 1988. Paleoclimate proxy from freshwater arctic diatoms. Verh. int. Ver. Limnol., 23: 837-844.

Smol, J.P., I.R. Walker \& P.R. Leavitt. 1991. Paleolimnology and hindcasting climatic trends. Verh. int. Ver. Limnol., 24: $1240-1246$

Sommaruga, R. \& F. Garcia-Pichel. 1999. UV-absorbing mycosporine-like compounds in planktonic and benthic organisms from a high-mountain lake. Arch. Hydrobiol., 144: 255-269.

van der Knaap, W.O., J.F.N. van Leeuwen, A. Fankhauser \& B. Ammann. 2000. Palynostratigraphy of the last centuries in Switzerland based on 23 lake and mire deposits: chronostratigraphic pollen markers, regional patterns, and local histories. Review of Palaeobotany and Palynology, 108: 85-142.

van der Vijver, B. \& L. Beyens. 1997a. The chrysophyte stomatocyst flora of the moss vegetation from Stromness Bay Area, South Georgia. Archiv der Protistenkunde, 148: 505-520.

van der Vijver, B. \& L. Beyens. 1997b. The subfossil chrysophyte cyst flora of some peat samples from Kerguelen Islands. Archiv der Protistenkunde, 148: 491-503.

Vinebrooke, R.D. \& P.R. Leavitt. 1996. Effects of ultraviolet radiation on periphyton in an alpine lake. Limnol. Oceanogr., 41: 1035-1040.

Vorobyova, S.S., G.V. Pomazkina, E.Y. Baranova, V. Likoshway \& P.D. Sandgren. 1996. Chrysophycean cysts (stomatocysts) from lake Baikal and Irkutsk Reservoir, Siberia. J. Paleolimnol., 15: 271-277.

Wick, L. \& W. Tinner. 1997. Vegetation changes and timberline fluctuations in the Central Alps as indicators of Holocene climatic oscillations. Arctic and Alpine Research, 29: 445-458.

Wiederholm, T. 1983. Chironomidae of the Holarctic Region, part 1. Larvae. Ent. scand. Suppl., 19: 1-457.

Wilkinson, A.N., B.A. Zeeb, J.P. Smol \& M.S.V. Douglas. 1997. Chrysophyte stomatocyst assemblages associated with periphytic, high arctic pond environments. Nordic Journal of Botany, 17: 95-112.

Zeeb, B.A., C.E. Christie, J.P. Smol, D.L. Findlay, H.J. Kling \& H.J.B. Birks. 1994. Response of diatom and chrysophyte assemblages in Lake 227 sediments to experimental eutrophication. Can. J. Fish. aquat. Sci., 51: 2300-2311.

Zeeb, B.A., J.P. Smol \& S.L. Vanlandingham. 1996. Pliocene chrysophycean stomatocysts from the Sonoma Volcanics, Napa County, California. Micropaleontology, 43: 79-91.

Züllig, H. 1985. Carotenoids from plankton and phototrophic bacteria in sediments as indicators of trophic change: evidence from the Late-Glacial and early Holocene of Lobsigensee. Dissertationes Botanicae, 87: 143-147. 